\title{
Cohousing and Sustainability Rating Systems: Opportunities for Planning Groups and Developers
}

\author{
Lv Wei $^{1, *}$, April D. Allen ${ }^{2}$ and Lee Davis ${ }^{2}$ \\ ${ }^{I}$ Department of Art Design, Nantong Vocational University, Jiangsu Sheng, China; ${ }^{2}$ The School of Planning, Design and \\ Construction, Michigan State University, East Lansing, USA
}

\begin{abstract}
To identify specific priorities of existing cohousing residents with regard to sustainable building design and practice as outlined in the LEED for Homes design protocol. This article examined the level of importance of various sustainability features have with residents for cohousing residents in cohousing communities and Having an understanding of the environmental priorities of existing cohousing groups will give some direction to future residents and developers to focus on areas that are most appealing to those who choose to live in a socially connected community. Knowing that generations of users may have different priorities helps to target decisionmaking within a group so that consensus can be reached.
\end{abstract}

Keywords: Cohousing, Sustainable development, LEED, Rating systems, Green design, Green building.

\section{INTRODUCTION}

The target of this study from 2000 to 2009 is to examining that the importance of different sustainability features for those cohousing residents. The results suggest that the most people concentrate on returning can be showed through the sustainability measures. The study also tries to find the knowledge level of residents and their desire of having a home or community which measuring by the sustainability system and find different plans of sustainability according to difference age groups: younger, senior and retirement years. As a result, even though the initial cost is higher when choosing the cohousing, those people who are willing to live in a sustainable style and give supports by themselves of protecting the environment.

Green building, means that all types of resources being used efficiently as much as possible so as to conserve the energy and at the same time, keep the house comfortable. The United States Green Building Council (USGBC) established a rating system evaluating the sustainability of building project through several aspects.

General efficiency of a whole community is affected by the design and planning decisions which made by a cohousing group [1]. So this requires the group has ability to reach the sustainable requirement.

The United States Department of Energy (DOE) has set up the energy saving project called "ENERGY STAR ${ }^{\circledR}$ " and this project helps each family save more than $20 \%$ to $30 \%$ energy when constructing a house. From the data, there is $120800 \mathrm{Kwh}$ per year of the average electrical consumption

*Address correspondence to this author at the School of Planning, Design and Construction, Michigan State University, 552 West Circle Drive Room 201N, Human Ecology Building, East Lansing, MI 48824, USA;

Tel: 517.355.1166; E-mail: 452043132@qq.com from 1999 to 2001 and this project reduces $20 \%$ to $30 \%$ significant energy cost, in the meanwhile, decreasing the fossil fuels burning emissions that contribute to global warming. (NAHB, 2006). Besides the "ENEGY STAR" project, there is also a third party system rating system named LEED measuring and calculating the high performance design, sustainable design methods and durability of buildings for various categories of buildings by accumulating points.Eight categories contains 35 topics are designed by LEED rating system to measure the sustainability of buildings and their contributing process.

New Urbanism concept motivates the sustainability design of cohousing communities, which aims to provide a healthier and more supportive cities, areas and neighborhoods includes the respect of history area, location for the climate and a green space area. Meltzer (2000) utilized the study zone to prove that cohousing model can achieve environmental degradation by conserving energy and the study illustrates that cohusing is a better sustainable model than other housing options, because in the social network that established by itself, it fulfills all sustainable requirements. A strong social network can foster the sustainability for both communities and individuals by achieving the sharing of resources and environment concerns. One of the important factors that can affect the cohousing design is that residents' participation. Residents' opinion shows directly affect the cohousing design details such as water and cooling heat and energy [2].

\section{METHODOLOGY}

The survey instrument is designed to test how sustainability affects the energy efficiency, indoor air quality, material use, as well as locating amenities containing life style information and demographics. This survey aims to illustrate 
Table 1. Survey contents.

\begin{tabular}{|l|l|l|l|}
\hline Questsionaire Sections & Contents & Subcontents & Notes \\
\hline \hline Section 1 & Demographic information & $\begin{array}{l}\text { Age, education level, knowledge of sustain- } \\
\text { ability rating systems, location and home } \\
\text { size }\end{array}$ & Categorical scale \\
\hline $\begin{array}{l}\text { Sections } \\
2 \text { and } 3\end{array}$ & $\begin{array}{l}\text { Opinions on sustainable con- } \\
\text { struction and amenities that can } \\
\text { facilitate sustainability ratings }\end{array}$ & $\begin{array}{l}\text { Energy conservation methods, water conser- } \\
\text { vation methods, materials, conditions that } \\
\text { affect indoor air quality and location }\end{array}$ & $\begin{array}{l}\text { Likert type scale: } \\
\text { (1) Stronglydisagree to } \\
\text { (5) Strongly agree }\end{array}$ \\
\hline Section 4 & $\begin{array}{l}\text { Self-assessment on lifestyles and } \\
\text { health }\end{array}$ & $\begin{array}{l}\text { Personal reflections on sustainability and } \\
\text { environmental issues that may affect health }\end{array}$ & $\begin{array}{l}\text { Likert type scale: } \\
\text { (1)Strongly disagree to } \\
\text { (5) Strongly agreeas well as yes/no }\end{array}$ \\
\hline Section 5 & Group decision making & $\begin{array}{l}\text { Education level of sustainable building prac- } \\
\text { tices and amenities }\end{array}$ & $\begin{array}{l}\text { Likert type scale: } \\
\text { (1) Strongly disagreeto } \\
\text { (5) Strongly agree }\end{array}$ \\
\hline
\end{tabular}

which kinds of features play the most important function when residents deciding the cohousing. The survey was completed via the surveymonkey.com The questionnaire composes six sections that designing based on LEED rating system.Likert type scale are used to check the sustainable decisions made by residents in order to calculate the sustainable construction value when building a neighborhood community [3].

The questionnaire for the survey consisted of six sections, with no open ended questions. Sections two and three of the survey paralleled many of the items on the LEED for Homes checklist to identify if the sustainability factors that are measured with this rating system are of significant importance to cohousing residents and to identify priorities of the cohousing residents for building sustainably. The survey instrument utilized a Likert type scale to examine the residents' decisions for building sustainably in order to determine the value of sustainable construction within the larger group context of building a neighborhood community [4]. Section four of the survey identified lifestyle issues for the cohousing resident and their perception of others in the community. Section five of the survey identified possible areas of conflict with group decision making as it pertained to sustainability (see Table 1).

\section{RESULTS}

Table 2 is the general statistics of those residents who choose cohousing model. From the result it can show that $40 \%$ people approach the senior years, otherwise less than $10 \%$ beyond the age 65 . Of the 88 residents, most of them are well educated, almost every are bachelor degree and more $60 \%$ are master's degree or higher. Half of them live in urban areas. A large proportion of people have already living in cohousing model at least one year.

Table 3 states the knowledge level of residents for those existing sustainability rating system. The results show that 97.7\%, almost all people recognize the "ENERGY STAR" program. $78.4 \%$ percentage of people have learned the LEED rating system, as a reason of short establishment history the recognition percentage is lower than that ENERGT STAR. However, as for NAHB green building modeling, the recognition percentage is much lower when comparing to the other two which is only approximately $50 \%$.

Table 2. Demographic characteristics.

\begin{tabular}{|c|c|c|}
\hline & $\begin{array}{l}\text { Frequency } \\
\text { (N) }\end{array}$ & $\begin{array}{c}\text { Percentage of Total } \\
(\%)\end{array}$ \\
\hline \multicolumn{3}{|l|}{ Age } \\
\hline $35-50$ years & 31 & 35.2 \\
\hline $50-65$ years & 35 & 39.8 \\
\hline $65-75$ years & 16 & 18.2 \\
\hline 75 years and over & 6 & 6.8 \\
\hline TOTAL & 88 & 100 \\
\hline \multicolumn{3}{|l|}{ Education Level } \\
\hline Some College & 3 & 3.4 \\
\hline College Degree & 31 & 35.2 \\
\hline Master's Degree or Higher & 54 & 61.4 \\
\hline TOTAL & 88 & 100 \\
\hline \multicolumn{3}{|l|}{ Location Designation } \\
\hline Urban & 49 & 56.3 \\
\hline Suburban & 21 & 24.1 \\
\hline Rural & 17 & 19.6 \\
\hline TOTAL & 87 & 100 \\
\hline \multicolumn{3}{|l|}{ Tenure in Cohousing } \\
\hline 1 year or less & 11 & 12.5 \\
\hline 1 to 5 years & 43 & 48.9 \\
\hline 6 to 10 years & 30 & 34.1 \\
\hline More than 10 years & 4 & 4.5 \\
\hline TOTAL & 88 & 100 \\
\hline
\end{tabular}


Table 3. Respondents' knowledge level of sustainability rating systems.

\begin{tabular}{|c|c|c|}
\hline & Frequency $(\mathbf{N})$ & Percentage of Total $(\%)$ \\
\hline \multicolumn{3}{|c|}{ Has heard the term "Energy Star" (United State Department of Energy Program) in regard to home building construction } \\
\hline Yes & 86 & 97.8 \\
\hline No & 1 & 1.1 \\
\hline Don’t Know & 1 & 1.1 \\
\hline TOTAL & 88 & 100 \\
\hline \multicolumn{3}{|c|}{ Has heard the term "LEED" (Leadership in Energy and Environmental Design) } \\
\hline Yes & 69 & 78.4 \\
\hline No & 18 & 20.5 \\
\hline Don’t Know & 1 & 1.1 \\
\hline TOTAL & 88 & 100 \\
\hline \multicolumn{3}{|c|}{ Has heard the term "NAHB Model Green Homebuilding Guidelines" (National Association of Home Builders) in regard to building construction } \\
\hline Yes & 44 & 50 \\
\hline No & 37 & 42 \\
\hline Don’t Know & 7 & 8 \\
\hline TOTAL & 88 & 100 \\
\hline
\end{tabular}

Table 4. Water and energy saving strategies for the common house.

\begin{tabular}{|c|c|c|}
\hline & Frequency (N) & Percentage of Total $(\%)$ \\
\hline \multicolumn{3}{|c|}{ The common house must be planned with ENERGY STAR doors and windows } \\
\hline Strongly agree & 58 & 65.9 \\
\hline Somewhat agree & 22 & 25 \\
\hline TOTAL & 80 & 90.9 \\
\hline \multicolumn{3}{|c|}{ The common house must be planned with ENERGY STAR appliances } \\
\hline Strongly agree & 49 & 55.7 \\
\hline Somewhat agree & 30 & 34.1 \\
\hline TOTAL & 79 & 89.8 \\
\hline \multicolumn{3}{|c|}{ The common house must be planned with enhanced insulation } \\
\hline Strongly agree & 63 & 71.6 \\
\hline Somewhat agree & 14 & 15.9 \\
\hline TOTAL & 77 & 87.5 \\
\hline \multicolumn{3}{|c|}{ The common house must be planned with energy saving technologies such as compact fluorescent lighting fixtures } \\
\hline Strongly agree & 57 & 64.8 \\
\hline Somewhat agree & 20 & 22.7 \\
\hline TOTAL & 77 & 87.5 \\
\hline \multicolumn{3}{|c|}{ The common house must be planned with high efficiency water heaters } \\
\hline Strongly agree & 54 & 61.4 \\
\hline Somewhat agree & 22 & 25 \\
\hline TOTAL & 76 & 86.4 \\
\hline \multicolumn{3}{|c|}{ The common house must be planned with water saving-technologies such as low-flow faucets and dual-flush toilets } \\
\hline Strongly agree & 49 & 55.7 \\
\hline Somewhat agree & 23 & 26.1 \\
\hline TOTAL & 72 & 81.8 \\
\hline
\end{tabular}


Table 5. Water and energy saving strategies for cohousing homes.

\begin{tabular}{|c|c|c|}
\hline \multicolumn{3}{|c|}{ My home must be planned with ENERGY STAR appliances } \\
\hline Somewhat agree & 14 & 15.9 \\
\hline TOTAL & 79 & 89.8 \\
\hline Strongly agree & 67 & 76.1 \\
\hline Somewhat agree & 12 & 13.6 \\
\hline TOTAL & 79 & 89.7 \\
\hline \multicolumn{3}{|c|}{ My home must be planned with energy saving technologies such as compact fluorescent lighting fixtures } \\
\hline TOTAL & 78 & 88.7 \\
\hline \multicolumn{3}{|c|}{ My home must be planned with double or triple pane windows } \\
\hline Strongly agree & 64 & 72.7 \\
\hline Somewhat agree & 13 & 14.8 \\
\hline TOTAL & 77 & 87.5 \\
\hline \multicolumn{3}{|c|}{ My home must be planned with water saving technologies such as low-flow faucets and dual-flush toilets } \\
\hline Strongly agree & 45 & 51.1 \\
\hline Somewhat agree & 25 & 28.4 \\
\hline \multicolumn{3}{|c|}{ My home must be planned with a high efficiency water heater } \\
\hline Strongly agree & 36 & 40.9 \\
\hline Somewhat agree & 29 & 33 \\
\hline TOTAL & 65 & 73.9 \\
\hline \multicolumn{3}{|c|}{ My home must have a high efficiency heating and cooling system } \\
\hline Strongly agree & 34 & 38.6 \\
\hline Somewhat agree & 30 & 34.1 \\
\hline TOTAL & 64 & 72.7 \\
\hline
\end{tabular}

As mention in the introduction part, feature of sustainability that cohousing residents most concern is that visible return given by sustainability on their investment. Therefore, the return can show by water and energy savings. Those savings will reflect on their bills with smaller amount of money [5]. Yet more than 80 percent of cohousing residents show their wills that there are many places of the sustainable de- sign need to be improved. For examples, the sustainable system should assemble with higher efficiency mechanical equipment enhance insulation and isolation of windows and doors in order to let the communities more sustainable [6]. As long as for their own homes, 70 percent of people strongly agree that their water and energy saving technologies need to be improved. (see Tables $\mathbf{4}$ and $\mathbf{5}$ ). 
Table 6. Water and energy saving strategies for the common house by age group.

\begin{tabular}{|c|c|c|c|c|}
\hline & $\begin{array}{l}35 \text { to } 50 \\
\text { yrs old } \\
(n=31)\end{array}$ & $\begin{array}{l}50 \text { to } 65 \\
\text { yrs old } \\
(n=35)\end{array}$ & $\begin{array}{l}65 \text { to } 75 \\
\text { yrs old } \\
(n=16)\end{array}$ & $\begin{array}{c}75+\text { yrs } \\
\text { Old } \\
(n=6)\end{array}$ \\
\hline & $\begin{array}{c}\text { Percentage of Total } \\
(\%)\end{array}$ & $\begin{array}{c}\text { Percentage of Total } \\
(\%)\end{array}$ & $\begin{array}{c}\text { Percentage of Total } \\
(\%)\end{array}$ & $\begin{array}{c}\text { Percentage of Total } \\
(\%)\end{array}$ \\
\hline \multicolumn{5}{|c|}{ The common house must be planned with ENERGY STAR doors and windows } \\
\hline Strongly agree & 68 & 69 & 69 & 67 \\
\hline Somewhat agree & 32 & 19 & 31 & 16 \\
\hline TOTAL & 100 & 88 & 100 & 83 \\
\hline \multicolumn{5}{|c|}{ The common house must be planned with ENERGY STAR appliances } \\
\hline Strongly agree & 55 & 71 & 50 & 33 \\
\hline Somewhat agree & 42 & 19 & 50 & 50 \\
\hline TOTAL & 97 & 90 & 100 & 83 \\
\hline \multicolumn{5}{|c|}{ The common house must be planned with enhanced insulation } \\
\hline Strongly agree & 65 & 81 & 88 & 67 \\
\hline Somewhat agree & 25 & 13 & 6 & 16 \\
\hline TOTAL & 90 & 94 & 94 & 83 \\
\hline \multicolumn{5}{|c|}{ The common house must be planned with energy saving technologies such as compact fluorescent lighting fixtures } \\
\hline Strongly agree & 61 & 77 & 69 & 50 \\
\hline Somewhat agree & 33 & 13 & 25 & 33 \\
\hline TOTAL & 94 & 90 & 94 & 83 \\
\hline \multicolumn{5}{|c|}{ The common house must be planned with high efficiency water heaters } \\
\hline Strongly agree & 39 & 72 & 88 & 83 \\
\hline Somewhat agree & 48 & 19 & 6 & 0 \\
\hline TOTAL & 87 & 91 & 94 & 83 \\
\hline \multicolumn{5}{|c|}{ The common house must be planned with water saving technologies such as low-flow faucets and dual-flush toilets } \\
\hline Strongly agree & 55 & 63 & 56 & 50 \\
\hline Somewhat agree & 26 & 24 & 38 & 17 \\
\hline TOTAL & 81 & 87 & 94 & 67 \\
\hline
\end{tabular}

Tables 6 and 7 state technologies that applied in the common house and individual cohousing house show that residents, in age 50 to 65 and 65 to 75 these two intervals prefer invest on water and energies savings. Whereas those people who aged in 35 to 50 groups prefer investing more on cooling and heating system.

Material selections are integral to determining a home's sustainability rating. The LEED for Homes rating system is concerned with the homeowner's use of local materials, rapidly renewable materials, materials with recycled content and reuse of existing materials. The use of materials that contain recycled content as well as those that are rapidly renewable and local can save on the amount of virgin material used to create products, the clear-cutting of forests to provide wood and paper goods, and unnecessary transocianic transportation of materials among other forms of waste. Cohousing residents who participated in this survey, however, did not feel that material selection was as important as water or energy savings strategies. Less than half, $48.9 \%$ somewhat or strongly agreed that the common house must be built with materials found in their region (defined by LEED for Homes as within a 500 mile radius of the home) and just over half, $51.2 \%$ somewhat or strongly agreed that their own homes must be built with materials found in the region [7]. Slightly more, $60.3 \%$, somewhat or strongly agreed that recycled materials must be incorporated into the common house while only $51.1 \%$ somewhat or strongly agreed that recycled materials should be incorporated into their own homes. 
Table 7. Water and energy saving strategies for cohousing homes by age group.

\begin{tabular}{|c|c|c|c|c|}
\hline & $\begin{array}{l}35 \text { to } 50 \\
\text { yrs old } \\
(n=31)\end{array}$ & $\begin{array}{l}50 \text { to } 65 \\
\text { yrs old } \\
(n=35)\end{array}$ & $\begin{array}{l}65 \text { to } 75 \\
\text { yrs old } \\
(n=16)\end{array}$ & $\begin{array}{c}75+\text { yrs } \\
\text { Old } \\
(n=5)\end{array}$ \\
\hline & $\begin{array}{c}\text { Percentage of To- } \\
\text { tal } \\
(\%)\end{array}$ & $\begin{array}{c}\text { Percentage of Total } \\
(\%)\end{array}$ & $\begin{array}{c}\text { Percentage of Total } \\
(\%)\end{array}$ & $\begin{array}{c}\text { Percentage of Total } \\
(\%)\end{array}$ \\
\hline \multicolumn{5}{|c|}{ My home must be planned with ENERGY STAR appliances } \\
\hline Strongly agree & 84 & 81 & 67 & 60 \\
\hline Somewhat agree & 13 & 16 & 26 & 20 \\
\hline TOTAL & 97 & 97 & 93 & 80 \\
\hline \multicolumn{5}{|c|}{ My home must be planned with enhanced insulation } \\
\hline Strongly agree & 81 & 88 & 73 & 60 \\
\hline Somewhat agree & 13 & 9 & 20 & 40 \\
\hline TOTAL & 94 & 97 & 93 & 100 \\
\hline \multicolumn{5}{|c|}{ My home must be planned with energy saving technologies such as compact fluorescent lighting fixtures } \\
\hline Strongly agree & 77 & 72 & 53 & 40 \\
\hline Somewhat agree & 20 & 22 & 40 & 40 \\
\hline TOTAL & 97 & 94 & 93 & 80 \\
\hline \multicolumn{5}{|c|}{ My home must be planned with double or triple pane windows } \\
\hline Strongly agree & 65 & 90 & 73 & 100 \\
\hline Somewhat agree & 25 & 4 & 27 & 0 \\
\hline TOTAL & 90 & 94 & 100 & 100 \\
\hline \multicolumn{5}{|c|}{ My home must be planned with water saving technologoes such as low-flow faucets and dual-flush toilets } \\
\hline Strongly agree & 42 & 69 & 47 & 60 \\
\hline Somewhat agree & 35 & 22 & 46 & 0 \\
\hline TOTAL & 77 & 91 & 93 & 60 \\
\hline \multicolumn{5}{|c|}{ My home must have access to enough sunlight to warm the house in cooler months } \\
\hline Strongly agree & 53 & 50 & 47 & 20 \\
\hline Somewhat agree & 34 & 31 & 46 & 40 \\
\hline TOTAL & 87 & 81 & 93 & 60 \\
\hline \multicolumn{5}{|c|}{ My home must have a high efficiency water heater } \\
\hline Strongly agree & 45 & 48 & 40 & 20 \\
\hline Somewhat agree & 36 & 36 & 33 & 40 \\
\hline TOTAL & 81 & 84 & 73 & 60 \\
\hline \multicolumn{5}{|c|}{ My home must have a high efficiency heating and cooling system } \\
\hline Strongly agree & 35 & 52 & 38 & 20 \\
\hline Somewhat agree & 46 & 25 & 37 & 40 \\
\hline TOTAL & 81 & 77 & 75 & 60 \\
\hline
\end{tabular}


Table 8. Sustainable lifestyles.

\begin{tabular}{|c|c|c|c|c|}
\hline & $\begin{array}{c}\text { 35-50 yrs } \\
\text { Old } \\
(n=31)\end{array}$ & $\begin{array}{c}\text { 50-65 yrs } \\
\text { Old } \\
(n=35)\end{array}$ & $\begin{array}{c}\text { 65-75 yrs } \\
\text { Old } \\
(n=16)\end{array}$ & $\begin{array}{c}75+\text { yrs } \\
\text { Old } \\
(n=5)\end{array}$ \\
\hline & $\begin{array}{l}\text { Percentage of Total } \\
(\%)\end{array}$ & $\begin{array}{l}\text { Percentage of Total } \\
(\%)\end{array}$ & $\begin{array}{l}\text { Percentage of To- } \\
\text { tal }(\%)\end{array}$ & Percentage of Total (\%) \\
\hline \multicolumn{5}{|c|}{ My lifestyle is sustainable } \\
\hline Somewhat agree & 51.6 & 65.6 & 56.3 & 40 \\
\hline TOTAL & 61.3 & 65.6 & 68.8 & 80 \\
\hline \multicolumn{5}{|c|}{ My lifestyle now is more sustainble than it was one year ago } \\
\hline \multicolumn{5}{|c|}{ My lifestyle now is more sustainable than it was five years ago } \\
\hline Strongly agree & 38.7 & 58.1 & 46.7 & 0 \\
\hline Somewhat agree & 41.9 & 25.8 & 53.3 & 40 \\
\hline TOTAL & 80.6 & 83.9 & 100 & 40 \\
\hline \multicolumn{5}{|c|}{ Living in cohousing has made me more aware of sustainability } \\
\hline Strongly agree & 54.8 & 37.5 & 40 & 40 \\
\hline Somewhat agree & 22.6 & 50 & 33.3 & 20 \\
\hline
\end{tabular}

These lower numbers may reflect an expectation that the architect or developer will work to design the community with the best materials for the job rather than having the community demand that certain materials be used.

The respondents were much more in agreement about the durability of the materials that would be used for their community. Eighty-three percent of the respondents somewhat or strongly agreed that the materials used for the interior finishes of the common house must last a minumum of 10 years without replacement. In their own homes, $80.6 \%$ of the respondents somewhat or strongly agreed that finish materials used there must last a minimum of 20 years. Over half, $62.5 \%$ of the respondents already have some form of sustainable flooring installed in their homes (cork, linoleum or bamboo).

Cohousing is a process of learning how to communicate with and understand those who may soon become neighbors and friends. People come together to share experiences and knowledge. From these, there will be changes and growth in all of their lives. The survey asked if there had been changes in the respondents' view of their own sustainability over time and found that when looking at all age groups together, $62.5 \%$ of the respondents somewhat or strongly agree that they are living a sustainable lifestyle [8]. Over half, 56.8\% somewhat or strongly agree that they are more sustainable now than they were one year ago and $77.3 \%$ somewhat or strongly agree that they are more sustainable now than they were five years ago. Almost three-quarters, $74.9 \%$ of all respondents in all age groups somewhat or strongly agreed that living in cohousing had made them more aware of sustainability.

Table 8 illustrates this lifestyle change for various age groups that participated in the survey. It finds that a higher percentage of 65 to 75 year olds somewhat or strongly agree that they are more sustainable now than they were one or five years ago, but a higher percentage of 50 to 65 year olds somewhat or strongly agree that their increased awareness of sustainability is due to living in cohousing (see Table 8).

When asked if other members of the cohousing planning group brought more information on sustainability to the planning process, in most age groups more than half of the respondents somewhat or strongly agreed that this was the case [9]. Only the 65 to 75 years olds had fewer than half of the respondents somewhat or strongly agreed that others had more information on sustainability than they did. The 50 to 65 years olds and the 65 to 75 years olds groups had the highest percentage of respondents who believe that they would have built the same sustainability factors into a stand alone house as was incorporated into their cohousing home (see Table 9) [10]. 
Table 9. Sustainable information exchange.

\begin{tabular}{|c|c|c|c|c|}
\hline & $\begin{array}{c}\text { 35-50 yrs } \\
\text { old } \\
(n=31)\end{array}$ & $\begin{array}{c}\text { 50-65 yrs } \\
\text { old } \\
(n=35)\end{array}$ & $\begin{array}{c}\text { 65-75 yrs } \\
\text { old } \\
(n=16)\end{array}$ & $\begin{array}{c}75+\text { yrs } \\
\text { old } \\
(n=5)\end{array}$ \\
\hline & $\begin{array}{l}\text { Percentage of Total } \\
(\%)\end{array}$ & $\begin{array}{c}\text { Percentage of Total } \\
(\%)\end{array}$ & $\begin{array}{c}\text { Percentage of Total } \\
(\%)\end{array}$ & Percentage of Total (\%) \\
\hline \multicolumn{5}{|c|}{ Other members of the cohousing planning group had more information about sustainability than I did } \\
\hline Strongly agree & 30 & 30 & 18.8 & 20 \\
\hline Somewhat agree & 30 & 36.7 & 25 & 40 \\
\hline TOTAL & 60 & 66.7 & 43.8 & 60 \\
\hline \multicolumn{5}{|c|}{ If you had not moved into cohousing, would you have designed the same sustainability features into a stand alone house? } \\
\hline Yes & 48.4 & 62.4 & 62.5 & 40 \\
\hline No & 35.5 & 18.8 & 12.5 & 20 \\
\hline Don't know & 16.1 & 18.8 & 25 & 40 \\
\hline TOTAL & 100 & 100 & 100 & 100 \\
\hline
\end{tabular}

Finally, respondents were asked if they felt that they had given up some opportunities to save costs in order to attain some measure of sustainability, and if they were forced to accept some costs they did not want so that the group vision for sustainability in the community could be achieved. They were also asked about the importance of measuring the level of sustainability they may have achieved with their community and with their own homes. Over half of all respondents, $59.1 \%$ felt that they traded cost savings for sustainability, however, $69.3 \%$ did not feel that they were forced to accept additional costs for sustainability they did not feel was necessary. When examined by age group, $20 \%$ of the respondents aged 75 years old or older agree they were forced to accept additional costs for sustainability they did not feel was necessary. Of those aged 65 to 75 only $13.3 \%$ felt they were forced to accept additional costs; $6.3 \%$ of 50 to 65 year olds felt they were forced to accept additional costs, and $12.9 \%$ of those aged 35 to 50 felt they were forced to accept additional costs. This data would indicate that while some respondents felt that belonging to a cohousing community meant accepting additional unwanted costs for sustainability, for most the cost differential was an acceptable trade off to get the community they wanted and the sustainable features they felt were necessary.

Only $20.5 \%$ of all respondents strongly agreed that it was important to measure their home's sustainability, however, just under half, $48.9 \%$ somewhat agreed that this would be important for a $69.4 \%$ positive response. These figures are about the same when asked if measuring their community's level of sustainability was important with $21.5 \%$ of all respondents strongly agreeing that it was, and $48.9 \%$ somewhat agreeing to that statement for a $70.4 \%$ positive response.

When respondents who had heard of LEED were separated out from the general response population, a slightly smaller percentage felt that measurement of the home and community was necessary. Of those who had heard of LEED, only $45 \%$ somewhat agreed that measuring the home's sustainability was important but $21.7 \%$ strongly agreed that this should be done for a $66.7 \%$ positive response. When asked about measuring their community's sustainability, again $45 \%$ somewhat agreed that this was important, and only $17.4 \%$ strongly agreed that this step should be taken for a $62.4 \%$ positive response [11].

When looking at all 25 of the responding communities to the survey, 24 of them have community web-sites and all of those 24 with web-sites have some reference to the sustainability factors of their neighborhood. Clearly sustainability is a value that all of these communities have chosen to incorporate into their building project. It is a prominent value that they want to be recognized for as they present themselves to the world.

\section{DISCUSSION}

The research indicate that many sustainability measures the participating communities self-identify with high priority in the survey.

- While the investment in real estate

- Will continue to be centered around location

- The first priority of cohousing will continue of building a socially viable communitywith environmental sustainability factors.

- Priority to those who will be living there that they should be introduced in the early stages of community development. (either during the feasibility phase or in the Study Group I phase)

- Helping in establishing an achievable level of ecological sustainability that the community can commit to. This 
discussion should not be delayed to the Study Group II participatory design phase.

This study evaluates the priorities of those already living in a cohousing community, although the information can be projected out from the younger respondents as to possible priorities that these groups will have or when they consider moving from a multi-generational cohousing community to a senior cohousing community.

If the age groups of 35 to 50 and 50 to 65 plans to live out the rest of their lives in their current cohousing community, the choices made must support them as they progress through the aging process. Planning considerations for high indoor air quality and free access to all areas of the house without barriers of stairs or undersized doors must be a part of the planning process with a consensus of all neighbors that these design decisions are worth the investment.

Respondents to this survey were most in favor of sustainability measures that can show a return on their investment. Where future cost savings can be planned on, the response to implementing favorable sustainable features. Where sustainability measures are not immediately associated with a return for the investment made, the response was less favorable. This can be seen in the less enthusiastic response to the usage of local materials or materials with recycled content. Where a sustainability measure is associated with an established standard, such as ENERGY STAR, a brand that implies greater cost savings for future energy bills, the response is extremely favorable. Given this information, if the LEED for Homes standard establishes itself well and proves to the market that the return on investment to achieve a LEED for Homes' rating is high, the cohousing communities will incorporate this into their planning and design of the community as they have done with the ENERGY STAR products and ratings [12].

The 50 to 65 year olds who responded to this survey show themselves to lead the other age groups and prioritize more of the sustainability measures discussed. The 50 to 65 year old group had more respondents strongly agree that water saving technology and ENERGY STAR appliances be used in the common house.

This age group also had more residents strongly agree that water saving technologies, enhanced insulation, high efficiency water heaters and high efficiency heating and cooling equipment must be used in their own home.

- Those aged 75 or higher prioritized using double or triple pane windows in their home.

- The 35 to 50 year olds were most concerned with using ENERGY STAR appliances in their homes.

- The 50 to 65 year olds and the 65 to 75 year olds are leaders in prioritizing many sustainability measures that are a part of established sustainability rating systems in the marketplace today.

All age groups felt that there was some trade-off between cost savings and sustainability in the design and construction of their cohousing community; the 50 to 65 year olds, as apparent drivers of many of the sustainability measures implemented, were least likely to feel that they were forced into accepting sustainability measures they did not want. Almost three-quarters of the 50 to 65 year olds and the 35 to 50 year olds responded positively to the idea of measuring their home's sustainability, however, the 50 to 65 year olds were most enthusiastic about measuring their community's sustainability.

It appears that the older age groups are more concerned for the sustainability measures implemented and the rating of the community space and less concerned about these issues in their own individual spaces. This age group appears to want to lead by putting the community first, perhaps with the understanding that the individual homes will follow suit.

The longest lived sustainability measurement system, ENERGY STAR was recognized by almost all of those who participated in the survey. The enthusiasm for incorporating sustainability measures directly related to the ENERGY STAR label was also high, with nearly all of the respondents having a positive view of using ENERGY STAR appliances in the common house and in their own homes. The marketing efforts made by the Department of Energy in tagging products that can contribute to a higher energy efficiency level appears to be very successful with the respondents of this group, especially those aged 35 to 50 [7-9]. As our society has grown to recognize and look for labels that can signify quality or universal availability, the tagging of products with the ENERGY STAR label appears to resonate with younger cohousing residents. As this group ages and as cohousing grows to accommodate our aging society, the ability to reach a consensus decision in the group by associating buying decisions with a known entity's tag or logo may expedite the process of selecting products that can enhance a community's and a home's energy efficiency and overall sustainability.

As other rating systems grow in popularity and recognition, it is expected that the same enthusiasm that accompanies the ENERGY STAR rating methods will also grow to encompass a broader scope of sustainability that is covered in the LEED for Homes design protocol. This is an encouraging indicator that sustainable building features are a worthwhile investment and in the future will contribute to lower energy bills, less energy waste and a smaller carbon footprint for all cohousing residents. As with the ENERGY STAR rating system, having a known and proven entity to help identify a comprehensive rating system may attract younger cohousing residents who can reach consensus decisions based on criteria that meets an established standard. As LEED for Homes builds its recognition in the field of design and construction, this will become the tag that can drive planning decisions, just as the ENERGY STAR tag drives decisions today.

To this point in time, residents have brought their own choices and priorities to the group where consensus is then reached on the implementation of specific measures.

\section{CONCLUSION}

The current study illustrates the high level of acceptance of many of the measures that comprise the LEED for Homes design protocol. This measurement system incorporates the ENERGY STAR rating system as part of their more comprehensive sustainable building rating system. Understand- 
ing that cohousing groups already show themselves to be concerned about making sustainable choices that can be measured and rated should make the introduction of a formal rating system to the group planning sessions easier. The groups' high recognition of the ENERGY STAR label also indicates that as the LEED for Homes label becomes more recognized in the field of home construction, the more likely cohousing residents will be to gravitate toward using this as a measure of sustainability.

\section{CONFLICT OF INTEREST}

The authors confirm that this article content has no conflict of interest.

\section{ACKNOWLEDGEMENTS}

Declared none.

\section{REFERENCES}

[1] Bachhuber J A, Sipple D, Voorhees J. A Case Study: Meeting Numeric Stormwater Criteria at a Foundry Site Through Model Application[J]. Rev.inst.adolfo Lutz, 2012, 71(3): 593-596.

[2] Barr S, Shaw G, Coles T. Sustainable Lifestyles: Sites, Practices, and Policy[J]. Environment \& Planning A, 2011, 43(12): 30113029 .
[3] Britt M L, Sullivan R S, Kora A R, et al. Energy Provisions of the ICC-700, LEED for Homes, and ENERGY STAR Mapped to the 2009 IECC[J]. 2011.

[4] Daskolia M, Kynigos C. CONSTRUCTING DIGITAL GAMES ABOUT SUSTAINABLE LIFESTYLES: CREATIVITY IN LEARNING TO LEARN TOGETHER[J]. 2012.

[5] Emma Aston. Childminding : guidance to the national standards : revisions to certain criteria : version $2[\mathrm{~J}]$. Phoenix, 2012, 66(3/4): 247-271.

[6] Hittinger E, Mullins K A, Azevedo I L. Electricity consumption and energy savings potential of video game consoles in the United States[J]. Energy Efficiency, 2012, 5(4): 531-545.

[7] Lampkin S R, Lampkin S R. Exploring life events that promote sustainable lifestyles[J]. Journal of Environmental Psychology, 2014.

[8] Lim S R, Schoenung J M. Measurement and analysis of product energy efficiency to assist energy star criteria development: An example for desktop computers[J]. Energy Policy, 2011, 39(12): 8003-8010.

[9] Mont O, Neuvonen A, Lähteenoja S. Sustainable lifestyles 2050: stakeholder visions, emerging practices and future research $[\mathrm{J}]$. Journal of Cleaner Production, 2014, 63(2): 24-32.

[10] Rabb A E. A Study to Increase Participation of Habitat for Humanity Affiliates in LEED for Homes Certification[J]. 2013.

[11] Santamaria L. Switch the Channel: A design framework for transitioning mainstream audiences to sustainable lifestyles[C]// DesRes 2014, Loughborough Design School. 2014.

[12] Shirani F, Butler C, Henwood K, et al. 'I' $m$ not a tree hugger, I' $m$ just like you' : changing perceptions of sustainable lifestyles[J]. Environmental Politics, 2015, 24(1): 57-74.

Received: April 10, 2015

Revised: May 20,2015

Accepted: June 15, 2015

(C) Wei et al.; Licensee Bentham Open

This is an open access article licensed under the terms of the (https://creativecommons.org/licenses/by/4.0/legalcode), which permits unrestricted, noncommercial use, distribution and reproduction in any medium, provided the work is properly cited. 